\title{
Developing Thematic-Integrated Module Based on Guided Discovery to Improve Critical Thinking and Student Science Attitude
}

\author{
Ningrum Perwitasari ${ }^{1} *$, D. Djukri ${ }^{1}$ \\ ${ }^{1}$ Department of Primary Education, Graduate School of Universitas Negeri Yogyakarta. \\ Jalan Colombo No. 1, Karangmalang, Yogyakarta, 55281, Indonesia. \\ *Corresponding Author. Email: ningrumperwitasari@gmail.com \\ Received: 10 August 2017; Revised: 2 January 2018; Accepted: 9 January 2018
}

\begin{abstract}
Abstrak
This research aimed (1) to produce thematic-integrated module based on a guided-discovery to improve critical thinking and scientific attitude of grade IV students of SDN Margoyasan, and (2) to know the effectiveness of the developed learning module. The research was Research and development of Borg and Gall model which consisted of ten steps. The data were collected by interview, product evaluation, questionnaires, observation, and examination. The data were analyzed by using paired sample t-test and independent sample t-test with significant level of 0.05 . The research result were (1) thematic-integrated module based on a guided-discovery. The product feasibility that was assessed based on material expert, media expert, teacher's and student's responses was very feasible. (2) The results of field trial test showed that the developed thematic-integrated module based on a guided-discovery was effective to improve the student's critical thinking and scientific attitude, and it was based on the operational field trial test which obtained $p<0.05$, means that there are significant differences on students who were taught by using the developed learning module compare to student who were not taught by using the developed learning module.
\end{abstract}

Keywords: thematic-integrated module based on a guided-discovery, critical thinking, scientific attitude.

How to Cite: Perwitasari, N., \& Djukri, D. (2018). Developing thematic-integrated module based on guided discovery to improve critical thinking and student science attitude. Jurnal Prima Edukasia, 6(1), 44-55. doi:http://dx.doi.org/10.21831/jpe.v6i1.15218

Permalink/DOI: http://dx.doi.org/10.21831/jpe.v6i1.15218

\section{Introduction}

Teachers should understand the character, cognitive developmental conditions, and affective and psychomotor developmental conditions of their students before the teachers begin the learning process. The cognitive development condition is the main issue of the learning process. The intellectual development levels of elementary school (SD) students are in concrete operational level. In this level, the students of elementary school have been able to take logical decisions from concrete issues but they have not been able to deal the abstract problems and the thinking process has been able to accept the opinions of others.

There are two kinds of thinking process: low-order thinking and higher-order thinking. Higher-order thinking is a thinking process that requires a high mental process. Krathwohl (2002, p. 213) revised the Bloom's taxonomy and divided the thinking process into some parts; starting from remembering, understanding, applying, analyzing, evaluating, and creating. Based on the level of thinking, critical thinking is included in the higher-order thinking process.

Critical thinking refers to the review process of what is happening, what causes an event, what is involved in an event, and then, they will think to obtain a problem solving if they decide the event is a problem. The phenomenon is called as reflective thinking. In addition, critical thinking is also not easily to make decisions on the way or solutions of problem solving. In this issue, the decision is not only a reproduction of the results of past experience, but it is real solution with a new understanding. The decision-making is called as productive thinking. Critical thinking is a combination of two types of thinkings, which are reflective and productive thinking. It is accordance with Santrock (2008, p. 359) states 
that critical thinking involve of reflective, productive thinking, and evaluation of evidence.

Based on the definition of critical thinking, it may conclude the importance of critical thinking in daily life. Humans are always faced with the problem, and then they data to make logical decisions in the process. Making the right decision requires a critical thinking ability, it aims to decide that information is valid or not.

The critical thinking has characteristics. People who have critical thinking are always having a high curiosity, easy to receive an information, believe the information with a reason, open minded, flexible, able to judge wisely, wise in judging, reconsider a thing, explicit in facing-the problems, able to do many things, and persevering to find out the outcome or solution of problems (Thompson, 2011).

Before improving the critical thinking ability, there are some things that need to consider in students' characteristic. Bailin, Case, Coombs, \& Daniels (1999, pp. 290-295) states some of the intellectual abilities are needed to do critical thinking process, namely: having knowledge regarding the way of the standard of thinking, having knowledge of the key concepts of critical thinking, heuristics and habitual in thinking.

Not only does critical thinking involve the cognitive domain, but the attitude and psychomotor aspects must also be developed in learning. Related to the 2013 curriculum, the approach is a scientific approach that is identical to the science. In the attitude or affective, the scientific attitude is expected to arise through a scientific approach. Scientific attitude is the attitude in a person to find and develop new knowledge. And, the scientific attitude should not only be applied to the science but extent. Moore \& Sutman (1970, pp. 85-94) states, a scientific attitude is an attitude toward a particular opinion, or position taken by a person due to considering the physical objects in the field of science.

Generally, there are seven types of scientific attitude according to experts, those are; curiosity, humility, distrust, open minded, dogmatic avoidance, positive attitude toward failure, and objectivity (Barba, 1998, p. 10).

By the definition and types of scientific attitudes, the habituation of curiosity, humility, distrust, open minded, dogmatic avoidance, positive attitude toward failure, and objective, those indirectly will occur more frequently. The attitude reflects good manners. Therefore, the scientific attitudes through learning indirectly will raise the students' awareness to become a good person or having noble character (Samatowa, 2010, p. 97).

During observation in SDN (State Elementary School) Margoyasan on 20, 22, and 23 July 2016, teachers used various learning models and media but the center of the learning was still teachers. The teachers only showed the media without involving students. Teachers had also used various lecture learning models with assignments, but teachers were not yet able to optimize the learning and attract the students' attention. During the learning, $70 \%$ of 20 students were inactive and showed enthusiasm to follow the learning.

In addition, based on observations in grade IV of class A and B, when a student asked a question - then, the student's question just repeated the teacher's explanation. And also, when the teacher delivered-question, the student's answers were exactly the same as the teacher's explanation. Students were not able to think beyond the learning. It shows that the students' thinking was not critical thinking yet.

During the learning process, the students did less visible scientific attitude. The students' scientific attitude was just open minded, while other scientific attitudes such as curiosity, humility, distrust, dogmatic avoidance, positive attitude toward failure, and objectivity had not yet emerged. The students' curiosity toward new things had not emerged by looking at silent students' expression - students that did not give questions were evidence of the low students' curiosity. Students also just nodded their head to new material presented by teacher without clarifying (deliver question) the truth; it illustrated that the students still easily believed with the new things. Objectivity attitude also had not emerged; when the teacher gave-a hypothesis, then students would say yes due to their assumption that the teacher argument was true. In fact, the teacher is also human and could be wrong in making a hypothesis.

The main learning resources of students were also limited to the 2013 curriculum book and teacher explanations. Based on teacher' explanation, the book of 2013 curriculum of grade IV in class A and B was not complete; the teacher still used books of Curriculum Level of Educator Unit (KTSP). Students were only used writing what the teacher wrote on the board; but when the teacher forgot to write material on the 
Jurnal Prima Edukasia, 6 (1), January 2018 -46

Ningrum Perwitasari, D. Djukri

board and it did not exist in the book, the student would not know. In terms of assessment, teachers quite had difficulty to assess the student learning outcomes. Teachers were not familiar with descriptive assessment. The findings about the ineffectiveness of instructional materials were also found in a study by Purnomo \& Wilujeng (2016, pp. 67-68).

Teachers ever used learning module as a teaching material. Teachers were quite interested in the module because the material is thorough, simple, and able to make the students learn independently compared to using textbook material that sometimes textbook's content are not complete. Teachers also tried to make a module, but it took a long time to make a module and cost to copy the module for student in whole class. Teachers need a learning material resource which is simple, complete, and systematic such as modules.

Regarding the critical thinking problem, teachers tried to make practice tasks with highlevel revision of Bloom's taxonomy, but students founf it difficult to solve. Only three students obtained score above 60 . It was most likely because the teacher also did not make a balance to the high-level question with the learning model. Teachers had also tried brainstorming model by giving a particular topic, but only one or two students wanted to give their opinion. It was probably because of the lack of several of brainstorming learning models, or because of the lack of interesting material or the lack of preparation in terms of material for discussion before starting the brainstorming learning process.

Regarding the problem of less students' scientific attitudes, teachers tried to improve the students' scientific attitudes by implementing science models of demonstration learning on magnetic materials; but due to media limitation, students could only watch from backside and students who sit at the backside found it difficult even to see the experiments by teachers. The teacher also had-requested the students in each group to come forward, but, it spent a lot of time. Teachers had also conducted outside classroom learning to observe leaf types, but teachers paid less attention to the points of the scientific approach and forgot the students to make hypothesis. All efforts by teachers have not succeeded maximally, teachers need more planning to do a certain learning model to improve the critical thinking ability and students' scientific attitude that sometimes teachers face the problem of media and time limitation.

Basically, there are several teaching materials such as books and modules, but the modules have advantages such as a complete structured and usability by students independently. Module teaching materials have the advantages to training the students learn independently. Amri (2013, p. 98) formulates the module as a thorough learning program, organized systematically, based on learning objectives, and independent learning materials. If compared with book, the advantages of module are on the communication which is usually in two directions and module attempts to replace some teachers' roles. Through the module, students of elementary school are expected to understand more and are led during the learning process with teaching materials that are not one-way communication.

Meanwhile, various models of learning may be used to create students' critical thinking ability and scientific attitude. But, learning discovery model will be more appropriate for students' characteristics and cognitive development. The learning model emphasizes the students' ability to investigate a relation, collects data to reinforce a relation, and use it to discover the applicable law or principle with an inductive thinking orientation. Students are expected to construct their own knowledge. Teachers do not play a role as presenters and information demonstrators, but play a role only as facilitators. Arends (2008, p.48) states that discovery learning emphasizes on student-centered active learning where the students find their own ideas and draw the meaning.

Discovery learning has several types, namely pure discovery and guided discovery. Guided discovery is a learning model that emphasizes the learning to discover but a teacher guides the students during the process of discovery learning activities. Teachers' guidance in learning is expected to instruct the students in students' discovery activities to achieve the learning goal. However, the teachers' guidance is not such kind of obligation rules, but the teachers' guidance is in the form of instruction about working procedures. Through discovery learning model, students are invited to learn independently and it is expected to make students understand the real problems and train their cognitive, affective, and psychomotor skills. Similar findings by Kristiani \& Prasetyo (2016), showed that the use of concrete objects 
Jurnal Prima Edukasia, 6 (1), January 2018 -47

Ningrum Perwitasari, D. Djukri

in learning is able to improve the students' cognitive ability and skills.

The integration of the module and guided discovery may quite appropriate. Guided discovery is a learning model that focuses on learning in the systematic thinking process of search and discovery. Guided discovery activities become the main activities in the module. And then, the module not only contains the material and do the tasks, but also has meaningful learning activities. In addition, module of guided discovery able to replace the role of teachers' guidance, such in making opinion / hypothesis - which module provides words to guide students learning discovery. It is appropriate to module characteristics by Amri (2013, p. 99), states that the module should prioritize the module user learning activities and attempts able to replace the teacher roles.

Integrative thematic modules based on guided discovery, it aims to prepare the students in order they have rationality and high creativity. Students will solve the problem without eliminating their thinking of logic through critical thinking. And, students will apply good scientific attitudes in face the various problems in daily life through scientific attitude.

\section{Method}

Developmental Model

In the module development, researcher used Borg and Gall model. The Borg \& Gall development model includes ten activities, which are: (1) research and information collecting, (2) planning, (3) develop preliminary forms of product (4) preliminary field testing, (5) main product revision, (6) main field testing, (7) operational product revision, (8) operational field testing, (9) final product revision, and (10) dissemination and implementation (Borg \& Gall, 1983, pp. 775-776).

Testing Design

Product testing to developed integrative thematic module based on guided discovery in the research consisted of several stages: (1) product validation by material expert and product validation by media expert (2) revision according to expert suggestion, (3) preliminary field testing, (4) revision of preliminary field testing, (5) main field testing, (6) revision of main field testing, (7) operational field testing, (8) revision of operational field testing;

\section{Testing Subject}

The testing subjects in the preliminary testing were 6 students of grade IV SD N (State Elementary School) Margoyasan which were student's ability category of low, medium, and high. The testing subjects of field testing were 12 students of grade IV SD N Margoyasan who have not included as the subject of preliminary testing. Operational field testing involved two classes: experimental class and control class of grade IV SDN Margoyasan of and total subjects were 40 students and 2 teachers.

\section{Data Collection Instruments}

The research instruments in the research were divided into two. First, instrument to measure the validity of the developed product included of: (1) questionnaire of media expert validation, (2) questionnaire of material expert validation, (3) questionnaire of teacher response toward developed product, (4) questionnaire of student response toward developed product. Second, instruments to measure the effectiveness of developed products included of: (1) essay to pretest and posttest and (2) scientific observation scale.

Data Type

The research data were a) data validation of media expert and material expert about product feasibility of integrative thematic module based on guided discovery, b) data of teachers' response and students' response toward developed module, 3) data of critical thinking test result, and 4) scientific attitudes scale.

\section{Data Analysis Technique}

In the study, the data were analyzed to determine the validity or feasibility developed modules to be use in the learning process, to improve the critical thinking ability and scientific attitudes. The effectiveness of developed module aims to improve the students' critical thinking and scientific attitudes. To know the quality of integrative thematic module based on guided discovery in the study consisted of several developments from the aspect both of display and content or material to know the teacher and student response toward integrative thematic module based on guided discovery. And then, quantitative data were described to be qualitative data which refers to five-scale guideline from the category of very good to bad. 


\section{Jurnal Prima Edukasia, 6 (1), January 2018 -48}

Ningrum Perwitasari, D. Djukri

\section{Results and Discussions}

Research Result

\section{Development of Initial Product}

The first stage of the research and development was need assessment. This stage was through four ways: literature review, interviews toward teachers in grade IV, observation of teaching and learning activities in grade IV, and documents review that used by teachers and students in teaching and learning activities.

The first step in the product development was theme selection. The theme of the module was the treasure of my country, with sub theme of treasure of energy resources in my country. After select the appropriate subthemes, it continue to preparation of the product.

The preparation of the product begins with the determination of the module sections. In the module sections, the sequence of module preparation included of title of the page, introduction, table of contents, module information, module usage instructions, core competency of grade IV sub theme 1 theme 9, $\mathrm{KD}$ (basic competence) mapping and Indicator, scope of sub theme 1 theme 9, learning concept maps 1 to 6 , learning activities 1 to 6 , glossary of difficult words, key answer of critical thinking practice in learning activities 1 to 6 , and bibliography. In the first step, it determines the title of the page relate to the guided discovery theme of treasure of energy resources in my country.

Not only materials are associated with the environment, but also each material in the guided discovery module combines the three subjects in one sub theme. For example, the material at the first meeting on the treasure of water resources, students are asked to understand how the process of energy water changes into electricity with the simple invention in small groups. In learning, students are not directly informed about the material, but they find the material. At the beginning, students are asked to argue or guess what will happen with the experiment, and then students do experiments to prove their arguments to find out their arguments are right or wrong.

And next, the scientific attitudes are developed through guided discovery activities. If the students find wrong arguments, teacher will give information about the error of the experiment and resulted to their arguments are different from the findings. Arguments become an exercise for students to do critical thinking, starting from read the sources material before experiment and students' critical thinking ability, students are asked to predict what will happen with the experiment. Critical thinking exercises are also given in each exercise question in the end of activity.

In each material text and experiment activities, researcher uses illustrations of images to make students interest to read and do the experiment. The text also uses a simple vocabulary in order the students may ease to understand. It aims to create a communicative module and increasing the students' enthusiastic to learn.

\section{Product Testing Description}

The product of integrative thematic learning modules based on guided discovery was assessed with the aspects of: (1) content compatibility, (2) language, 3) completeness of module, (4) display, (5) graph, (6) guided discovery content, and (7) principle of elementary school students learning.

Aspects of product assessment are assessed by an expert or a validator. Validators of the product are media experts and material experts. The obtained data in the development research are the result of product feasibility assessment given by media experts and material experts. Expert validation has purpose to obtain suggestions both oral in discussions and written on developed modules before the preliminary testing. After the module is feasible, it continues to test in the field test. Score conversion guide for validation results are based on interval conversion formula. Based on the results of score conversion calculation, the summary data of the assessment results of the material experts is presented in Table 1.

Table 1. Results of Module Feasibility Assessment by Material Expert

\begin{tabular}{|c|c|c|c|}
\hline No. & Sub-Variabel & $\begin{array}{c}\text { Score } \\
\text { Results } \\
\end{array}$ & Category \\
\hline 1. & Content compatibility & 38 & $\begin{array}{c}\text { Very } \\
\text { Feasible }\end{array}$ \\
\hline 2. & language & 22 & Feasible \\
\hline 3. & $\begin{array}{l}\text { Characteristic of } \\
\text { integrative thematic } \\
\text { learning }\end{array}$ & 10 & $\begin{array}{c}\text { Very } \\
\text { Feasible }\end{array}$ \\
\hline & Total & 70 & $\begin{array}{c}\text { Very } \\
\text { Feasible }\end{array}$ \\
\hline
\end{tabular}

Based on Table 1, developed and validated product of integrative thematic module based on guided discovery by material expert is 
Jurnal Prima Edukasia, 6 (1), January 2018 -49

Ningrum Perwitasari, D. Djukri

"feasible to use with revision" and the details of the assessment results is presented in Table 1 . The content compatibility aspect is feasible to use with "very feasible" category according to content compatibility indicator toward KI (core competence) and KD (Basic competence), learning activities, material content, and advantages of module that obtained score of 38. Aspects of language is feasible to use with "feasible" category according to indicators of readability of contents module, clear of module information, compatibility the module with EYD (Indonesia Language Dictionary Guide), and the language in the module obtained score of 22. Furthermore, in the aspects of learning characteristics obtained "very feasible" category according to indicators of subject combination in a learning activity and steps of scientific approach obtained score of 10.

Based on those aspects, the overall result of the feasibility assessment of integrative thematic module based on guided discovery is involved in the "very feasible" category and the total score is 70 . The suggestions provided by the expert for the developed module are (1) writing the sources in the module needs to follow the guidance writing, (2) LKS (students' worksheet) is attempted to use the image in order LKS is more clear, and (3) the sentences must clear and do not use ambiguity sentences both in paragraph text and questions/tasks.

After the module is feasible, it continues to field testing. The guidelines of score conversion for validation results are based on the interval conversion formula. Based on the results of the score conversion calculation, the summary data of the assessment results from the material experts is presented in Table 2.

Table 2. Results of Module Feasibility Assessment by Media Expert

\begin{tabular}{|c|c|c|c|}
\hline No. & Sub-Variabel & $\begin{array}{c}\text { Score } \\
\text { Results }\end{array}$ & Category \\
\hline 1. & Display Aspect & 26 & $\begin{array}{c}\text { Very } \\
\text { Feasible }\end{array}$ \\
\hline 2. & Graph Aspect & 36 & $\begin{array}{c}\text { Very } \\
\text { Feasible }\end{array}$ \\
\hline 3. & $\begin{array}{l}\text { Module } \\
\text { Characteristic }\end{array}$ & 24 & $\begin{array}{c}\text { Very } \\
\text { Feasible }\end{array}$ \\
\hline & Total & 72 & $\begin{array}{c}\text { Very } \\
\text { Feasible }\end{array}$ \\
\hline
\end{tabular}

Based on Table 2, developed and validated product of integrative thematic module based on guided discovery by media expert is "feasible to use with revision" and the details of the assessment results is presented in Table 2 .
Aspects of display is in "very feasible" category according to indicators of the material module coherent, module motivation content, completeness of information and communicative presentation that obtained score of 26. Aspect of graph is in "very feasible" category according to indicators of letters type, font size, illustration and image, proportional design, and module attractiveness that obtained score of 36 .

Furthermore, in the aspects of module characteristic is in "very feasible" category according to indicators of growth the student self-learning, the nature of the module intact, independent of other media, reflect the daily events, and flexibility to the development that obtained score of 24 . Based on those aspects, the overall result to module feasibility assessment is involved in "very feasible" category and the total score is 72 . The suggestions provided by the expert for the developed module are (1) the text writing in the table should use a left-handed format, (2) added illustrations to the appropriate text, and (3) revise the blur of using color block in subtitle.

After conducted revision based on experts' suggestions, the integrative thematic modules based on project-based learning have stated as feasible by media experts and material experts. The next step is preliminary test. The test conducted to 6 students of grade IV SD N Margoyasan. Preliminary test aims to gain information, suggestion, and advice from students and teachers about the modules. The teachers' response questionnaire result in the preliminary test is presented in Table 3 .

Table 3. Teachers' response questionnaire result in the preliminary test

\begin{tabular}{|c|c|c|c|}
\hline No & Aspect & $\begin{array}{l}\text { Total } \\
\text { Score }\end{array}$ & Category \\
\hline 1 & Content Compatibility & 36 & $\begin{array}{c}\text { Very } \\
\text { Feasible }\end{array}$ \\
\hline 2 & Language & 20 & Feasible \\
\hline 3 & $\begin{array}{l}\text { Thematic learning } \\
\text { characteristic }\end{array}$ & 10 & $\begin{array}{c}\text { Very } \\
\text { feasible }\end{array}$ \\
\hline 4 & Display & 26 & $\begin{array}{c}\text { Very } \\
\text { feasible }\end{array}$ \\
\hline 5 & Graph & 36 & $\begin{array}{c}\text { Very } \\
\text { feasible }\end{array}$ \\
\hline 6 & Module characteristic & 25 & $\begin{array}{c}\text { Very } \\
\text { feasible }\end{array}$ \\
\hline
\end{tabular}

Based on Table 3, the developed module according to the aspect of content compatibility, language, thematic learning characteristics, display, graph, and the module characteristic is involved to very feasible category. In sum, the 
developed module is feasible to use. In the preliminary test, it obtained students' response data through students' response questionnaire instrument. The score of questionnaire results of students' response in the preliminary test are presented in Table 4.

Table 4. Students' response questionnaire result in the preliminary test

\begin{tabular}{cccc}
\hline No & Subject & Total Score & Category \\
\hline 1 & MI & 11 & Very Feasible \\
2 & MS & 11 & Very Feasible \\
3 & DA & 10 & Very Feasible \\
4 & AM & 11 & Very Feasible \\
5 & YD & 10 & Very Feasible \\
6 & FA & 11 & Very Feasible \\
\hline
\end{tabular}

Based on Table 4, the developed modules according to aspects of graph, content or material, and guided discovery content is involved in very feasible category. In sum, the developed module is feasible to use.

After conducted revision based on response of teachers and students, the next step is field test. The revised learning modules continue to test to 1 teacher and 12 students with different capabilities from grade IV SD N Margoyasan. Field test aims to obtain scores and collecting information about response of teacher and student toward revised learning modules. The result data of teacher' response questionnaire in field test is presented in Table 5.

Table 5. Students' Response Result

\begin{tabular}{cccc}
\hline No. & Subject & Total Score & Category \\
\hline 1. & RW & 11 & Very Feasible \\
2. & MP & 10 & Very Feasible \\
3. & CR & 11 & Very Feasible \\
4 & GA & 11 & Very Feasible \\
5. & IA & 11 & Very Feasible \\
6. & AG & 11 & Very Feasible \\
7. & KV & 10 & Very Feasible \\
8. & RM & 11 & Very Feasible \\
9. & IH & 11 & Very Feasible \\
10. & GK & 11 & Very Feasible \\
11. & AP & 10 & Very Feasible \\
12. & MR & 11 & Very Feasible \\
\hline
\end{tabular}

Based on Table 5, the developed modules according to the aspects of graph, content or material, and guided discovery content is involved in very good categories. In sum, the developed module is feasible to use. The result of teacher's response in the field test has converted to five-point scale and presented in Table 5.

Based on Table 5, the developed module according to the aspects of content com- patibility, language, thematic learning characteristics, display, graph, and content module characteristic is involved in very feasible category. In sum, the developed module is feasible to use. The teacher's response results are presented in Table 6 .

Table 6. Teacher's Response Result

\begin{tabular}{|c|c|c|c|}
\hline No. & Aspect & Score & Category \\
\hline 1. & Content Compatibility & 38 & $\begin{array}{c}\text { Very } \\
\text { Feasibility }\end{array}$ \\
\hline 2. & Language & 23 & $\begin{array}{c}\text { Very } \\
\text { Feasible }\end{array}$ \\
\hline 3. & $\begin{array}{l}\text { Thematic Learning } \\
\text { Characteristic }\end{array}$ & 10 & $\begin{array}{c}\text { Very } \\
\text { Feasible }\end{array}$ \\
\hline 4. & Display & 28 & $\begin{array}{c}\text { Very } \\
\text { Feasible }\end{array}$ \\
\hline 5 & Graph & 38 & $\begin{array}{c}\text { Very } \\
\text { Feasible }\end{array}$ \\
\hline 6. & Module Characteristic & 25 & $\begin{array}{c}\text { Very } \\
\text { Feasible }\end{array}$ \\
\hline
\end{tabular}

After field testing, the next step is operational testing. Operational testing conducted for 1 sub theme or 6 session of learning. The quasi experiment is used as method in operational testing which are class IV $\mathrm{A}$ as control class (KK) and class IV B as experiment class (KE). Operational field testing aims to determine the module effectiveness for students of grade IV elementary school. The pre-test, post-test, and scientific attitude observation scales were used as instrument in the research. The obtained data is the test results of critical thinking and the scale of students' scientific attitude.

Data of the test result of critical thinking is students' score of the essay's answer regarding the students' critical thinking. To know the quality of critical thinking, then the score is converted to five-point scale. The data result of the critical thinking test before and after using the integrative thematic learning module based on guided discovery that has been converted to five-point scale is presented in Table 7.

Table 7. Result of Students' Critical Thinking Test in the Operational Testing

\begin{tabular}{ccccc}
\hline \multirow{2}{*}{ Class } & \multicolumn{2}{c}{ Pre-test } & \multicolumn{2}{c}{ Post-test } \\
\cline { 2 - 5 } & Score & Predicate & Score & Predicate \\
\hline KK & 55,75 & C & 65,75 & B \\
KE & 56,26 & C & 72,25 & SB \\
\hline
\end{tabular}

Based on Table 7, the average of critical thinking ability before using integrative thematic module based on guided discovery in the experiment class is 56.25. After using the 
developed modules, the average scientific attitude increased by 16 to 72.25 . Meanwhile in control class, the average of critical thinking ability before using integrative thematic module based on guided discovery is 55.75 , and then, after using module increased by 10 to 65.75 .

Data of student observation result is scale of student's scientific attitude before and after using the module. To find out the quality of students' scientific attitude, the obtained scores are converted to five-point scale. The result of the data recapitulation scale of students' scientific attitude before using module has been converted to five-point scale and presented in Table 8 .

Table 8. Result of Students' Scientific Attitude in the Operational Testing

\begin{tabular}{ccccc}
\hline \multirow{2}{*}{ Class } & \multicolumn{2}{c}{ Pre-test } & \multicolumn{2}{c}{ Post-test } \\
\cline { 2 - 5 } & Score & Predicate & Score & Predicate \\
\hline KK & 11 & SB & 12,35 & SB \\
KE1 & 12,25 & SB & 13,8 & SB \\
\hline
\end{tabular}

Based on Table 8 , the average scientific attitude before using the module in experiment class is 12.25 . The average scientific attitude increased by 1.55 to 13.8 after using the developed module. Meanwhile in control class, the average scientific attitude before using module is 11 . The average scientific attitude increased by 1.35 to 12.35 after using the developed module.

After the prerequisite test, the next step is t-test which consists of independent t-test and paired t-test. Independent t-tests aim to identify the difference of the ability of critical thinking and scientific attitudes in experiment class using modules and control class using common teaching materials. Paired t-tests aim to identify the difference between students' critical thinking ability and students' scientific attitudes before and after learn using modules.

The independent t-test of critical thinking and students' attitude in control class and experiment class shows that the calculation result has a significance score of 0.000 or less than the $\mathrm{p}$ score of 0.05 . Means, there is a significant difference between the test result data of critical thinking ability and students' scientific attitude on control class and experiment class.

The result of paired t-test of critical thinking ability and student attitude in control class and experiment class show that the calculation score has a significance score of 0.000 or less than the $p$ score of 0.05 . Means, there is a significant difference between the test result data of critical thinking ability and students' scientific attitude on control class and experiment class. The result of paired t-test of students' critical thinking ability in operational test is presented in Figure 1. Means, there is significant differences in critical thinking ability and scientific attitude on experiment class before and after learning using module.

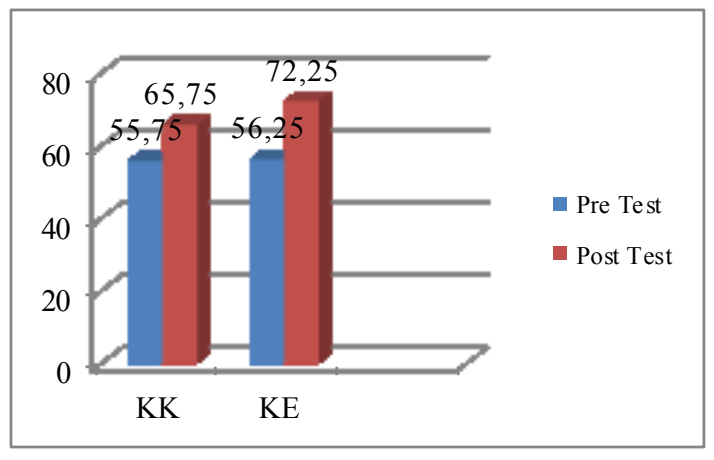

Figure 1. Diagram of Paired t-test result of Students' Critical Thinking ability.

Meanwhile, the paired t-test result of scale of students' scientific attitude in operational testing is presented in Figure 2.

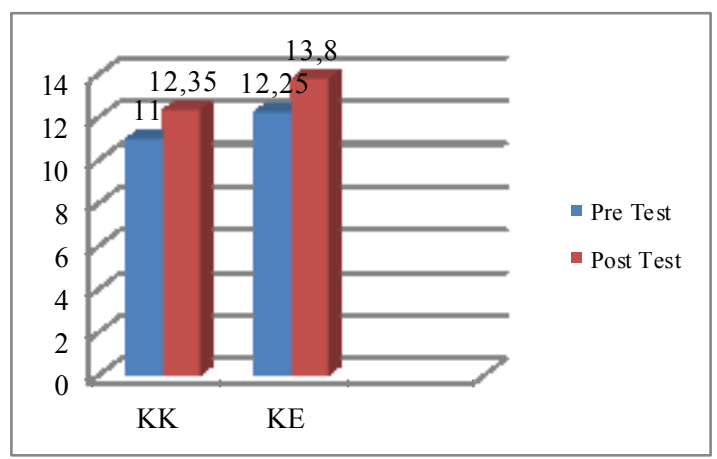

Figure 2. Diagram of paired t-test result of students' scientific attitude

The increasing of critical thinking ability and students' scientific attitudes in experiment class shows that the module is more effectively used to improve the critical thinking ability and scientific attitude on grade IV of elementary school.

\section{Discussion}

The research develops a module teaching materials. The developed module is an integrative thematic module based on guided discovery for grade IV of elementary school. After through several research steps by Borg \& Gall, the module is feasible to be used because 
Jurnal Prima Edukasia, 6 (1), January 2018 -52

Ningrum Perwitasari, D. Djukri

the module has validated by material experts and media experts.

In the material experts, developed module involves in the very feasible category. In the media experts, developed module involve in the very feasible category. Based on the assessment of experts, the developed module has appropriate with $\mathrm{KI}$ and KD, systematically, adapted to the students' environment, and appropriate with the students' level of thinking and interest.

In addition, developed modules are feasible according to module's criteria. The criteria of feasible modules are according to the theories that summarized by Departemen Pendidikan Nasional (National Education Board), namely self instructional, self-contained, stand-alone, adaptive, and user friendly, in terms of content compatibility, language, content, and graph (Departemen Pendidikan Nasional, 2008).

Modules provide many advantages in the learning process than using other teaching materials, such as students' focus attention. And this happens during the experiment in the experiment class. Modules are able to keep students' attention centered. Through the module, students will focus their attention to understand the module, the students will be guided to understand the purpose or importance of learning the material, students are also guided into the main learning activities, and the evaluation questions are summarized in one module. It is supported by Dimopoulos, Paraskevopoulos, \& Pantis (2009, p. 360), states that through modules can improve the students' knowledge, understanding, attention, and language skills.

Integrative thematic learning not only prioritizes on cognitive concepts, but also attitudes and skills. In developed modules, there is combination of guided discovery that emphasizes on learning through discovery of knowledge, and then students able to understand the learning meanings. It is appropriate to integrative thematic learning principles that also emphasize the learning through direct experience. Discovery learning in the module is guided by the teacher because the students is indeed in the thinking ability who still needs guidance in making simple argument and concluding result of experiment or other learning activity. And by teacher's guidance, the results of the discovery process would be more effective as Cohen (2008, p. 3) states that guided discovery learning would be more effective than direct instruction learning.

The purpose of integrative thematic modules based on guided discovery is to improve students' critical thinking and scientific attitudes. Critical thinking ability is required by students in face the problems in future. Scientific attitudes are also an important part of science learning. Without a scientific attitude, students will not open minded to a new knowledge. Scientific attitude will also be students' provisions to face the natural and social problems in the environment.

The increasing of students' critical thinking ability is conducted in the learning process of module. The sub theme is about "Treasure of Energy Resources in Indonesia". The learning activities are arranged as an effort to improve the students' critical thinking ability which are (1) to provide students an opportunity to read the text as relevant source to the teaching material, (2) students are asked to deliver unlimited questions, opinions, and responses about a thing during the learning process, (3) students are trained to make arguments that optimize their thinking ability; the argument is about the assumption of a problem in the discovery activity both in the form of experiment and analysis of a thing, (4) students are asked to conclude based on the experiment data and the analysis, 5) students are trained to do the essay tasks that implement critical thinking characteristics and through Bloom's taxonomy revision, and (6) students are trained to discover their knowledge, in order the obtained knowledge is more meaningful and store in long-term of the student's memory by teacher guidance.

Those activity is an implementation of Bailin's theory states that critical thinking is a mental process or skill in thinking and improving the critical thinking through practice (Bailin, 2002, p. 362). Through the practice of critical thinking, students will develop their critical thinking ability.

The assessment of critical thinking ability is conducted by providing tests in the beginning and end of the use of developed modules. Pretest is conducted to measure the level of students' critical thinking ability and post-test is conducted to measure the students' ability after treatment of the module use. Based on data of pre-test and post-test result obtained score before using product is 56.25 , and then after using product the score increase to 72.25 . The 
Jurnal Prima Edukasia, 6 (1), January 2018 -53

Ningrum Perwitasari, D. Djukri

increasing scores could be the reason for developing other modules because the module effectively improves the students' critical thinking ability.

The post-test result of experiment class shows that the average score of students before and after using module; there is an increasing of scientific attitude from 12.25 added 1.55 point to 13.8. It is also proved by the comparison of experiment and control class using existing materials or prepared by the Central Curriculum 2013. The average score of experiment class is 13.8 and control class obtains score of 12.35 , and then there is a difference of 1.55 . The effectiveness test of independent sample t-test using SPSS 16 also shows that the significance score of 0.000 is less than 0.05 , and there is a significant difference between experiment class and control class.

The critical thinking ability in the module is developed through guided discovery at every meeting. In addition, the critical thinking habitual is conducted through the practice questions at every meeting. The question of the practice uses questions with high cognitive levels of Bloom and it guide students to think more critically. The answer to the questions is open ended and then many questions that have no answer in reading text/book but already studied by students indirectly. From the practices, the result of students' post-test increased. Supported by Santrock (2008, p. 361) states that some strategies to improve the children's critical thinking may use thoughtbased questions. In line with Santrock, Juano \& Pardjono's research proves that learning begins with raising problems, questions, and argument able to improve the critical thinking ability (Juano \& Pardjono, 2016).

Learning by using integrative thematic modules based on guided discovery is designed by facilitating students to conduct learning by doing the process of self-discovery; it leads to meaningful learning. By the meaningful learning, the knowledge will be more stored in the students' memory. In addition, students also learn to use their thinking ability which the students usually are only asked to learn through the teacher's explanation or the students only receive information, but in the discovery activities students need to have direct experience about how the process of problems, argue the solution of the problem, collect data to support the argument, data processing, and conclude the findings. In those activities, students are required to think how to argue the problem solution and process the data by analyzing. Those activities will make students to think more critical. Carin \& Sund (1989, p. 95) states, beside they must have direct experience, the reasons to use discovery learning model are: (1) students' intellectual potential may develop through discovery, (2) intrinsic motivation will be built through discovery learning models and it is stronger than extrinsic motivation, and 4) retains the memory.

The improvement of students' scientific attitude is conducted in the learning process of the module. The sub-theme is about "Treasure of Energy Resources in Indonesia". Learning activities are arranged as an effort to improve the students' scientific attitude, which are (1) students are asked to read the reading sources carefully to train the rational attitude of students, it means-the students are asked to do not easy believe information without find out the appropriate source of information before decide a decision, (2) students are trained to deal with unique problems in discovery process activities and make argument that optimize the open scientific attitude and students' curiosity, (3) students are trained to work with their groups as a means to improve the students' scientific attitude that is objective-students should not support one decision before prove it scientifically, (4) the activity processes in the module is experiments and analysis of an issue to train students' scientific attitudes such as honesty, not easy believe in superstition, and decide a decision with consideration.

Those activities is the base reason of the Rao (2004, p. 9) that by providing an opportunity to discover their knowledgestudents will feel and develop their scientific attitude. Assessment of scientific attitude is conducted by observation at the beginning and end of the use of developed module. Based on the results data before and after using the developed module, it obtained score of 12.25 which increased to 13.8. The increasing scores could be the reason for developing other modules because the module effectively improves the students' scientific attitude.

Learning using guided discovery is not merely doing an experiment independently. Students learn to experience how to make something, prove their argument, process data based on their argument, also learn to accept the opinion of their teammates, and change opinion if not appropriate to data. There is a unique 
Jurnal Prima Edukasia, 6 (1), January 2018 -54

Ningrum Perwitasari, D. Djukri

thing happen in experiment class-there is an argument of a group that is different from the experiment's result. In contrast, other group is able to prove that the group's results are wrong. The group with the wrong result is able to accept and correct what making their discovery activity is wrong; in fact, they find a missing step of overall activity. Most of students have not analyzed yet something through reading but the students immediately decide a decision. The habituation of students' skills in comparing, predicting, processing data, will make a habitual of a students to real experience that leads to the scientific attitude. The scientific attitude will be very useful in face with the problems of natural and social problems around environment. It appropriates to Rao (2004, p. 157) states that person with a good scientific attitude will face critically to various natural and social problems.

Learning through guided discovery will be more challenging-students will be challenged to find solutions to the issues and students will also be more enthusiastic in learning. In operational testing, most of students are quite enthusiastic about discovery learning and the students' curiosity will be very visible in the activity. In the beginning of making argument, students are curious what makes the students argue A, or students also argue B. In the end, students become more spirit during the activity. As the result, many students are able to explain about the experiment in the question and answer session at the end of the activity. It will be different situation if the students only listen to the teacher's explanation and then do the task. By using the module, students learn independently and students can already understand when learning is complete, but if there is remaining time the students will read and try to understand the next material. It is appropriate to Howe \& Jones (1998, p. 172) states that many failures in students' material understanding because the presentation of the material is less interesting and inappropriate, then the learning must apply minds and hands on simultaneously.

In addition, the processes in guided discovery such as make an argument, do observation, collects the data, process data, and conclusions provide an impact to students' cognitive improvement. In guided discovery process, it needs ability to observe, compare, give an overview, argue, and deductive and inductive conclusions are ways to improve the students' cognitive abilities, including students' critical thinking ability. It is appropriate to Jacobsen, Eggen, \& Kauchak (1993, p. 187) states that guided discovery improves the students' thinking skills, including critical thinking.

\section{Conclusions}

The research result is a set of an integrative thematic learning module based on guided discovery that is feasible to use aiming to improve the critical thinking and scientific attitude in the grade IV of elementary school according to material expert and media expert with "very feasible" category. In addition, integrative thematic learning module based on guided discovery is effectively to improve the ability of students' critical thinking and scientific attitude of grade IV of elementary school.

The module may used by students as an alternative learning materials that may improve the ability of critical thinking and scientific attitude. Aim to obtain more valid of learning outcome, teachers are suggested to conduct pretest and post-test during the teaching and learning activities to measure the students' ability of critical thinking and scientific attitude.

\section{References}

Amri, S. (2013). Pengembangan dan model pembelajaran dalam kurikulum 2013. Jakarta: Prestasi Pustaka.

Bailin, S. (2002). Critical Thinking and Science Education. Science and Education, 11(4), 361-375.

https://doi.org/10.1023/A:1016042608621

Bailin, S., Case, R., Coombs, J. R., \& Daniels, L. B. (1999). Conceptualizing critical thinking. Journal of Curriculum Studies, 31(3), 285-302. https://doi.org/10.1080/002202799183133

Barba, R. H. (1998). Science in the multicultural classroom: A guide to teaching and learning. Allyn and Bacon.

Borg, W. R., \& Gall, M. D. (1983). Educational research: An introduction. New York: Longman.

Carin, A. A., \& Sund, R. B. (1989). Teaching science through discovery. London: Merrill.

Cohen, M. T. (2008). The effect of direct instruction versus discovery learning on the understanding of science lessons by second grade students. In NERA 
Jurnal Prima Edukasia, 6 (1), January 2018 -55

Ningrum Perwitasari, D. Djukri

Conference Proceedings 2008. Retrieved from

http://opencommons.uconn.edu/nera_200 $8 / 30$

Departemen Pendidikan Nasional. (2008). Panduan pengembangan bahan ajar. Jakarta: Departemen Pendidikan Nasional.

Dimopoulos, D. I., Paraskevopoulos, S., \& Pantis, J. D. (2009). Planning educational activities and teaching strategies on constructing a conservation educational modul. International Journal of Environmental and Science Education, 4(4), 351-364. Retrieved from http://www.ijese.net/makale/1402

Howe, A. C., \& Jones, L. (1998). Engaging children in science. New York, N.Y.: Merrill.

Jacobsen, D. A., Eggen, P. D., \& Kauchak, D. P. (1993). Methods for teaching: A skills approach. Ohio: Merrill.

Juano, A., \& Pardjono, P. (2016). Pengaruh pembelajaran problem posing terhadap kemampuan berpikir kritis dan komunikasi matematis siswa kelas V SD. Jurnal Prima Edukasia, 4(1), 46. https://doi.org/10.21831/jpe.v4i1.7801

Krathwohl, D. R. (2002). A revision of Bloom's taxonomy: An overview. Theory Into Practice, 41(4), 212-218. https://doi.org/10.1207/s15430421tip4104 2
Kristiani, N., \& Prasetyo, Z. K. (2016). Keefektifan pembelajaran metematika melalui penggunaan media benda konkret pada kelas V SD Timuran. Jurnal Prima Edukasia, $\quad 4(2), \quad 163$. https://doi.org/10.21831/jpe.v4i2.7791

Moore, R. W., \& Sutman, F. X. (1970). The development, field test and validation of an inventory of scientific attitudes. Journal of Research in Science Teaching, $7(2)$, $85-94$. https://doi.org/10.1002/tea.3660070203

Purnomo, H., \& Wilujeng, I. (2016). Pengembangan bahan ajar dan instrumen penilaian IPA tema indahnya negeriku penyempurnaan buku guru dan siswa kurikulum 2013. Jurnal Prima Edukasia, 4(1).

Rao, D. B. (2004). Scientific attitude, scientific aptitude and achievement. New Delhi: Discovery Pub. House.

Samatowa, U. (2010). Pembelajaran IPA SD. Jakarta: PT. Indeks Permata Puri Media.

Santrock, J. W. (2008). Psikologi pendidikan (Tri Wibowo). Jakarta: Kencana. https://doi.org/2008

Thompson, C. (2011). Critical thinking across the curriculum: Process over output. International Journal of Humanities and Social Science, 1(9). Retrieved from http://www.ijhssnet.com/journals/Vol._1_ No. 9 Special Issue July 2011/1.pdf 